\title{
PERSPEKTIF NEGARA HUKUM INDONESIA BERDASARKAN PANCASILA
}

\author{
Tengku Erwinsyahbana \\ Tengku Rizq Frisky Syahbana
Fakultas Hukum Universitas Muhammadiyah Sumatera Utara erwin6768@gmail.com
rizqfrisky11@gmail.com

\begin{abstract}
Abstrak
Konsep negara hukum (rechtstaats) di Indonesia harus sesuai dengan nilai-nilai yang tercermin dalam Pancasila. Pemahaman utuh terhadap konsep Negara Hukum yang berdasarkan Pancasila dapat dilihat dari proses dan latar belakang lahirnya rumusan Pembukaan UUD 1945 yang merupakan pernyataan kehendak lahirnya negara Indonesia, serta sebagai dasar filosofis dan tujuan negara. Unsur-unsur negara hukum Indonesia merupakan nilai yang dipetik dari seluruh proses lahirnya negara Indonesia, dasar falsafah serta cita hukum negara Indonesia. Oleh sebab itu, kedudukan Pembukaan UUD 1945 yang juga memuat rumusan Pancasila, menjadi sumber hukum tertinggi bagi negara hukum Indonesia. Pembukaan UUD 1945 merupakan nilai abstraksi tertinggi dan nilai yang terkandung dalam pembukaan merupakan kaedah penuntun penyusunan pasal-pasal dalam UUD 1945 agar tidak menyimpang dari nilai-nilai yang menjadi dasar falsafah dan cita negara
\end{abstract}

Kata Kunci: Negara Hukum, Pancasila, UUD 1945

\section{A. Pendahuluan}

Hakikat negara hukum didasarkan pada konsep teori Kedaulatan Negara (Soeverignty) yang pada prinsipnya menyatakan kekuasaan tertinggi di dalam suatu negara adalah hukum. Seluruh alat perlengkapan negara apa pun namanya, termasuk warga negara harus tunduk dan patuh serta menjunjung tinggi hukum tanpa kecuali. ${ }^{1}$ Konsep pemikiran negara hukum seperti ini sebenarnya dapat dilihat dari awal munculnya teori Negara Hukum yang dimulai sejak abad XIX hingga abad XX. ${ }^{2}$ Menurut Krabbe sebagaimana dikutip oleh

\footnotetext{
${ }^{1}$ B. Hestu Cipto Handoyo, Hukum Tata Negara, Kewarganegaraan \& Hak Asasi Manusia, Memahami Proses Konsolidasi Sistem Demokrasi di Indonesia, Yogyakarta: Universitas Atma Jaya, Cetakan Pertama, 2003, hlm. 12.

2 Krisna Harahap, HAM dan Upaya Penegakannya di Indonesia, Bandung: Grafitri Budi Utami, 2003, hlm. 22.
} 
Usep Ranawijaya disebutkan, bahwa negara sebagai pencipta dan penegak hukum dalam segala kegiatannya harus tunduk pada hukum yang berlaku. Dalam arti ini hukum membawahkan negara. Berdasarkan pengertian tersebut, hukum bersumber dari kesadaran hukum rakyat, maka hukum mempunyai wibawa yang tidak berkaitan dengan seseorang (impersona). ${ }^{3}$

Secara teoritis konsep negara hukum awalnya dikenal di negara-negara Eropa Kontinental dengan istilah Rechtstaat artinya negara berdasarkan hukum yang upayanya untuk membatasi dan mengatur kekuasaan. ${ }^{4}$ Paham ini berkembang di negara-negara Anglo Saxon khususnya di Inggris dengan sebutan The Rule of Law atau negara yang kekuasaannya dibatasi oleh hukum. ${ }^{5}$ Hukum menjadi salah satu unsur penting dalam kehidupan bernegara sebagaimana dikemukakan Sri Soemantri Martosoewignyo, bahwa negara yang dikategorikan sebagai negara hukum harus mempunyai unsur sebagai berikut: ${ }^{6}$

1. Pemerintah dalam melaksanakan tugas dan kewajibannya harus berdasarkan atas hukum atau peraturan perundang-undangan;

2. Adanya jaminan terhadap hak-hak asasi manusia (warga negara);

3. Adanya pembagian kekuasaan dalam negara; dan

4. Adaya pengawasan dari badan-badan peradilan (rechtterlijke controle).

Negara hukum menurut Friedrich Julius Stahl harus memenuhi unsurunsur utama negara hukum, yaitu: ${ }^{7}$

1. Mengakui dan melindungi hak asasi manusia;

2. Penyelenggaraan negara harus berdasarkan trias politica; 181.

${ }^{3}$ Usep Ranawijaya, Hukum Tata Negara, Dasar-dasarnya, Jakarta: Ghalia, 1983, hlm.

4 Dikatakan negara hukum lahir sebagai reaksi sistem pemerintahan absolute (absolutisme) yang tidak menghargai eksistensi hak asasi manusia. Lihat Muhammad Tahir Azhary (1), Negara Hukum Indonesia, Jakarta: UI-Press, 1995, hlm. 47.

5 Bagir Manan (ed), Kedaulatan Rakyat, Hak Asasi Manusia dan Negara Hukum, Kumpulan Essai Guna Menghormati Prof. Dr. Sri Soemantri Martosoewignyo, SH., Jakarta: Gaya Media Pratama, 1996, hlm. 77.

6 R. Sri Soemantri Martosoewignyo, Bunga Rampai Hukum Tata Negara Indonesia, Bandung: Alumni, 1992, hlm. 29. 151.

7 Padmo Wahyono (1), Pembangunan Hukum di Indonesia, Jakarta: In-Hill Co, 1989, hlm. 
3. Dalam menjalankan tugasnya, pemerintah harus berdasarkan pada undangundang; dan

4. Adanya peradilan administrasi negara.

Pendapat lain dari A.V. Dicey mengemukakan bahwa unsur utama pemerintahan yang kekuasaannya di bawah hukum negara adalah: ${ }^{8}$

1. Supremasi dari hukum, artinya bahwa yang mempunyai kekuasaan yang tertinggi di dalam negara adalah hukum (kedaulatan hukum);

2. Persamaan dalam kedudukan hukum bagi setiap orang; dan

3. Konstitusi itu tidak merupakan sumber dari hak-hak asasi manusia, dan jika hak-hak asasi manusia itu diletakkan dalam konstitusi itu hanya sebagai penegasan bahwa hak asasi itu harus dilindungi.

Menurut Von Munch sebagaimana dikutip A. Hamid S. Attamimi, dikatakan bahwa unsur negara berdasarkan atas hukum ialah adanya: ${ }^{9}$

1. Hak asasi manusia.

2. Pembagian kekuasaan.

3. Keterikatan semua organ negara pada undang-undang dasar dan keterikatan peradilan pada undang-undang dan hukum.

4. Aturan dasar tentang proporsionalitas (verhaltnismassingkeit).

5. Pengawasan peradilan terhadap putusan-putusan (penetapan-penetapan) kekuasaan umum.

6. Jaminan peradilan dan hak-hak dasar dalam proses peradilan.

7. Pembatasan terhadap berlaku surutnya undang-undang.

Berhubung bahwa salah satu unsur terpenting dalam negara hukum adalah keterikatan organ negara pada undang-undang dan hukum, maka peraturan perundang-undang atau dalam konteks lebih luas adalah hukum, haruslah dirumuskan secara jelas, tidak multitafsir, dan mampu mewujudkan kepastian hukum. Hal ini sesuai dengan pendapat Arif Hidayat, yang mengatakan bahwa secara umum konsep negara hukum pada prinsipnya mencakup empat tuntutan dasar, yakni: (1) kepastian hukum; (2) hukum berlaku sama bagi seluruh penduduk; (3) adanya legitimasi demokratis dalam pembuatan hukum;

\footnotetext{
${ }^{8}$ M. Kusnardi dan Harmailly Ibrahim, Pengantar Tata Hukum Negara Indonesia, Jakarta: UI-Press, 1983, hlm. 161.

${ }^{9}$ A. Hamid S. Attamimi, "Peranan Keputusan Presiden Republik Indonesia dalam Penyelenggaraan Pemerintahan Negara: Suatu Studi Analisa Mengenai Keputusan Presiden yang Berfungsi Pengaturan dalam Kurun Waktu Pelita I-Pelita IV", Disertasi, Jakarta: Fakultas Pascasarjana Universitas Indonesia, 1990, hlm. 312.
} 
serta (4) menjunjung tinggi martabat manusia. ${ }^{10}$ Demikian pula menurut Hans Kelsen yang dalam pandangannya mengatakan bahwa konsep rule of law (negara hukum) yang berarti penegakan hukum, maka: (1) hukum ditegakkan demi kepastian hukum; (2) hukum itu dijadikan sumber utama bagi hakim dalam memutuskan perkara; (3) hukum tidak didasarkan pada kebijaksanaan dalam pelaksanaannya; dan (4) hukum tersebut harus bersifat dogmatik. ${ }^{11}$

Pandangan tersebut di atas sesuai pendapat Gustav Radbruch ${ }^{12}$ yang mengatakan bahwa:

Gagasan hukum merupakan gagasan kultural tidak bisa formal, berarti terarah pada cita hukum (rechtsidee), yaitu keadilan. Untuk mengisi cita keadilan ini dengan isi yang konkrit harus dilihat dari sisi finalitasnya, dan untuk melengkapi cita hukum serta finalitas, dibutuhkan kepastian. Oleh sebab itu, hukum memiliki tiga aspek penting, yaitu: keadilan, kepastian dan finalitas. Aspek keadilan menunjukkan pada kesamaan hak di depan hukum, aspek finalitas menunjukkan pada tujuan keadilan yaitu memajukan kebaikan dalam hidup manusia, berarti menentukan isi hukum, sedangkan aspek kepastian menunjukkan pada jaminan bahwa hukum (yang berisi keadilan dan norma-norma yang memajukan kebaikan), dan benar-benar berfungsi sebagai peraturan yang harus ditaati. Aspek keadilan merupakan kerangka ideal dari hukum, sedangkan aspek kepastian merupakan kerangka operasional hukum.

Istilah negara hukum memang baru populer pada Abad XIX, tetapi teori Negara Hukum sebenarnya telah lama ada dan berkembang sesuai dengan tuntutan keadaan. Dimulai dari jaman Plato hingga kini, konsepsi tentang negara hukum banyak mengalami perubahan yang mengilhami ahli filsafat dan pakar hukum untuk merumuskan teori Negara Hukum dan hal-hal yang harus ada dalam konsep negara hukum. Plato dan Aristoteles misalnya, telah merumuskan bahwa negara hukum adalah negara yang diperintah oleh pemerintah negara yang adil. Dalam filsafatnya, disinggung angan-angan (cita-cita) manusia yang

\footnotetext{
${ }^{10}$ Arif Hidayat, "Kepastian Hukum Harus Sejalan dengan Rasa Keadilan" dalam Antara News, http://www.antaranews.com, diakses tanggal 12 November 2011.

${ }_{11}^{1}$ Astim Riyanto, Filsafat Hukum, Bandung: Yapemdo, 2002, hlm. 377.

12 Ibid.
} 
berkorespondensi dengan dunia yang mutlak yang disebut dengan: cita-cita untuk mengejar kebenaran (idée der warhead), cita-cita untuk mengejar kesusilaan (idée der zodelijkheid), cita-cita untuk mengejar keindahan (idée der schonheid), dan cita-cita untuk mengejar keadilan (idee der gorechtigheid). ${ }^{13}$

Konsep negara hukum lahir sebagai hasil perjuangan individu untuk melepaskan dirinya dari keterikatan serta tindakan sewenang-wenang penguasa. Atas dasar ini maka penguasa tidak dibenarkan melakukan tindakan sewenangwenang kepada individu dan kekuasaannya harus pula dibatasi. Pembatasan kekuasaan dapat dilakukan melalui undang-undang atau peraturan perundangundangan dan menurut Rukmana Amanwinata disebut dengan asas legalitas negara hukum. ${ }^{14}$

Melihat perkembangan teori Negara Hukum, terlihat bahwa dalam pengertian rechtstaat sering dikaitkan dengan pengertian demokrasi, sehingga pengertian negara hukum yang ideal adalah "negara hukum yang demokratis". Menurut Padmo Wahjono, ${ }^{15}$ bahwa inti perumusan hukum dalam suatu negara hukum harus terumus secara demokratis, yaitu memang dikehendaki oleh rakyat, karena kedaulatan tertinggi berada ditangan rakyat (tanpa ada pembatasan), ${ }^{16}$ akan menimbulkan absolute-demokratic, yang tidak berbeda sifatnya dengan

${ }^{13}$ Lihat dalam Moh. Kusnardi dan Bintan Saragih, IImu Negara, Jakarta: Gaya Media, Edisi Revisi, Cetakan Keempat, 2000, hlm. 131. Demikian pula Krabe, telah merumuskan bahwa negara sebagai pencipta dan penegak hukum di dalam segala kegiatannya harus tunduk pada hukum yang berlaku, dalam arti ini hukum membawahi negara. Hukum itu bersumber dari kesadaran hukum rakyat, maka hukum mempunyai wibawa yang tidak berkaitan dengan seseorang (impersonal). Lihat dalam Usep Ranawijaya, Op. Cit., hlm. 181.

${ }^{14}$ Rukmana Amanwinata, "Pengaturan dan Batas Implementasi Kemerdekaan Berserikat dan Berkumpul dalam Pasal 28 UUD 1945", Disertasi, Bandung: Program Pascasarjana Universitas Padjadjaran, 1996, hlm. 122-123.

15 Padmo Wahjono (2), Indonesia Negara Berdasarkan Atas Hukum, Jakarta: Ghalia Indonesia, Cetakan Kedua, 1986, hlm. 8-9.

${ }^{16}$ Sebelum amandemen, tidak ada batasan yang jelas tentang pelaksanaan kedaulatan tertinggi berada ditangan rakyat, karena dalam Pasal 1 ayat (2) UUD 1945 ditegaskan bahwa kedaulatan adalah di tangan rakyat, dan dilakukan sepenuhnya oleh Majelis Permusyawaratan Rakyat. Setelah amandemen ketiga UUD 1945, maka kedaulatan rakyat ini mempunyai batasan yaitu dilaksanakan menurut Undang-Undang Dasar. 
kekuasaan tidak terbatas pada satu orang diktator maupun pada sekelompok orang diktator (diktatur proletariaat). Oleh sebab itu, menurut Padmo Wahjono bahwa rumusan yang terdapat dalam alinea keempat Pembukaan UUD 1945 (memuat sila-sila Pancasila), merupakan jaminan pembatasan bagi kemungkinan timbulnya demokrasi yang absolut, bahkan jaminan ini lebih tegas jika dibandingkan dengan rumusan negara hukum yang demokratis atau sebaliknya negara demokrasi yang dibatasi oleh pola negara hukum.

Menurut Scheltema sebagaimana yang dikutip B. Arief Sidharta, telah dirumuskan pandangan tentang unsur-unsur dan asas-asas negara hukum, yang meliputi 5 (lima) hal sebagai berikut: ${ }^{17}$

1. Pengakuan, penghormatan dan perlindungan HAM yang berakar dalam penghormatan atas martabat manusia (human dignity).

2. Berlakunya asas kepastian hukum, karena negara hukum bertujuan untuk menjamin terwujudnya kepastian hukum dalam masyarakat. Hukum bertujuan untuk mewujudkan kepastian hukum dan prediktabilitas yang tinggi, sehingga dinamika kehidupan bersama dalam masyarakat bersifat "predictable". Asas-asas yang terkandung dalam atau terkait dengan asas kepastian hukum itu adalah:

a. asas legalitas, konstitusionalitas, dan supremasi hukum;

b. asas undang-undang menetapkan berbagai perangkat peraturan tentang cara pemerintah dan para pejabatnya melakukan tindakan pemerintahan;

c. asas non-retroaktif perundang-undangan, sebelum mengikat undangundang harus lebih dulu diundangkan dan diumumkan secara layak;

d. asas peradilan bebas, independen, imparsial, dan objektif, rasional, adil dan manusiawi;

e. asas non-liquet, hakim tidak boleh menolak perkara karena alasan undang-undangnya tidak ada atau tidak jelas; dan

f. hak asasi manusia harus dirumuskan dan dijamin perlindungannya dalam undang-undang atau UUD.

3. Berlakunya persamaan (similia similius atau equality before the law), karena dalam negara hukum, pemerintah tidak boleh mengistimewakan orang atau kelompok orang tertentu atau mendiskriminasikan orang atau kelompok orang tertentu. Di dalam prinsip ini terkandung jaminan persamaan bagi semua orang di hadapan hukum dan pemerintahan dan tersedianya mekanisme untuk menuntut perlakuan yang sama bagi semua warga negara.

${ }^{17}$ Bernard Arief Sidharta (1), "Kajian Kefilsafatan tentang Negara Hukum”, dalam Jurnal Hukum Jentera, Jakarta: Pusat Studi Hukum dan Kebijakan (PSHK), Edisi 3-Tahun II, November 2004, hlm. 124-125. 
4. Asas demokrasi, bahwa setiap orang mempunyai hak dan kesempatan yang sama untuk turut serta dalam pemerintahan atau untuk mempengaruhi tindakan-tindakan pemerintahan. Asas demokrasi tersebut diwujudkan melalui beberapa prinsip sebagai berikut:

a. adanya mekanisme pemilihan pejabat-pejabat publik tertentu yang bersifat langsung, umum, bebas, rahasia, jujur dan adil yang diselenggarakan secara berkala;

b. pemerintah bertanggungjawab dan dapat dimintai pertanggungjawaban oleh badan perwakilan rakyat;

c. semua warga negara memiliki kemungkinan dan kesempatan yang sama untuk berpartisipasi dalam proses pengambilan keputusan politik dan mengontrol pemerintah;

d. semua tindakan pemerintahan terbuka bagi kritik dan kajian rasional oleh semua pihak;

e. kebebasan berpendapat/berkeyakinan dan menyatakan pendapat;

f. kebebasan pers dan lalu lintas informasi; dan

g. rancangan undang-undang harus dipublikasikan untuk memungkinkan partisipasi rakyat secara efektif.

5. Pemerintah dan pejabat mengemban amanat sebagai pelayan masyarakat dalam rangka mewujudkan kesejahteraan masyarakat sesuai dengan tujuan bernegara yang bersangkutan. Dalam asas ini terkandung hal-hal berikut:

a. asas-asas umum pemerintahan yang layak;

b. syarat-syarat fundamental bagi keberadaan manusia yang bermartabat manusiawi dijamin dan dirumuskan dalam aturan perundang-undangan, khususnya dalam konstitusi;

c. pemerintah harus secara rasional menata tiap tindakannya, memiliki tujuan yang jelas dan berhasil guna (doelmatig), artinya pemerintahan itu harus diselenggarakan secara efektif dan efisien.

\section{B. Perspektif Negara Hukum Indonesia}

Istilah negara hukum di Indonesia sering disebut dengan rechtstaats atau the rule of law. Paham rechtstaats pada dasarnya bertumpu pada sistem hukum Eropa Kontinental dan walaupun dalam UUD 1945 istilah negara hukum disebut rechtstaats, tetapi secara normatif harus dibedakan dengan paham negara hukum dalam sistem hukum Eropa Kontinental ataupun konsep the rule of law dalam sistem hukum Anglo Saxon. Konsep negara hukum (rechtstaats) di Indonesia harus sesuai dengan nilai-nilai yang tercermin dalam Pancasila. Pemahaman utuh terhadap konsep Negara Hukum yang berdasarkan Pancasila dapat dilihat dari proses dan latar belakang lahirnya rumusan Pembukaan UUD 
1945 yang merupakan pernyataan kehendak lahirnya negara Indonesia, serta sebagai dasar filosofis dan tujuan negara. Dari kajian dan pemahaman demikian, akan sampai pada suatu kesimpulan bahwa dalam konsep Negara Hukum yang berdasarkan Pancasila selain memiliki kesamaan, tetapi juga memiliki perbedaan dengan konsep negara hukum yang dikembangkan di negara lain. ${ }^{18}$

Negara hukum Indonesia yang dapat juga diistilahkan sebagai negara hukum Pancasila memiliki latar belakang kelahiran yang berbeda dengan konsep negara hukum yang dikenal di barat, walaupun Negara hukum sebagai genus begrip yang tertuang dalam Penjelasan UUD 1945 terinspirasi dari konsep negara hukum yang dikenal di barat dan jika membaca dan memahami yang dibayangkan Soepomo ketika menulis Penjelasan UUD 1945 jelas merujuk pada konsep rechtstaat, karena negara hukum dipahami sebagai konsep barat. $^{19}$ Terinspirasi dari konsep negara hukum barat dalam hal ini rechtstaat, maka UUD 1945 menghendaki elemen-elemen rechtstaat maupun rule of law menjadi bagian dari prinsip-prinsip Negara Hukum Indonesia. ${ }^{20}$

\footnotetext{
${ }^{18}$ Negara hukum dalam perspektif Pancasila, selain memiliki elemen-elemen yang sama dengan elemen negara hukum dalam rechtstaat maupun rule of law, juga memiliki elemen-elemen yang spesifik yang menjadikan Negara Hukum Indonesia berbeda dengan konsep negara hukum yang dikenal secara umum. Perbedaan itu terletak pada nilai-nilai yang terkandung dalam Pembukaan UUD 1945 yang di dalamnya mengandung Pancasila dengan prinsip-prinsip Ketuhanan Yang Maha Esa, serta tidak adanya pemisahan antara negara dan agama, prinsip musyawarah dalam pelaksanaan kekuasaan pemerintahan negara, prinsip keadilan sosial, kekeluargaan dan gotong royong serta hukum yang mengabdi pada keutuhan negara kesatuan Indonesia. Lihat dalam Hamdan Zoelva, "Negara Hukum dalam Perspektif Pancasila," http://www. setneg. go.id, diakses tanggal 2 November 2010.

${ }_{19}$ Satjipto Rahardjo mengatakan bahwa negara hukum adalah konsep modern yang tidak tumbuh dari dalam masyarakat Indonesia sendiri, tetapi "barang impor". Negara hukum adalah bangunan yang "dipaksakan dari luar". Lebih lanjut menurut Satjipto, proses menjadi negara hukum bukan menjadi bagian dari sejarah sosial politik bangsa kita di masa lalu seperti terjadi di Eropa, tetapi apa yang dikehendaki oleh keseluruhan jiwa yang tertuang dalam Pembukaan dan Pasalpasal UUD 1945, demikian juga rumusan terakhir negara hukum dalam UUD 1945 setelah perubahan adalah suatu yang berbeda dengan konsep negara hukum barat dalam arti rechtstaat maupun rule of law. Lihat dalam Satjipto Rahardjo, Membedah Hukum Progresif, Jakarta: Penerbit Buku Kompas, 2006, hlm. 48.

${ }^{20}$ Tengku Erwinsyahbana, "Sistem Hukum Perkawinan pada Negara Hukum Berdasarkan Pancasila”, Jurnal IImu Hukum, Vol. 2 No. 2, Pekanbaru: Fakultas Hukum Universitas Riau, 2012, hlm. 173
} 
Negara hukum itu bukan suatu jenis dan watak negara yang datang dengan sendirinya. Realisasi negara hukum harus diperjuangkan, sebab walaupun ditetapkan dengan peraturan negara, bahwa harus diakui supremasi yang mutlak dari hukum, aspek materil dan formil-organisatoris, aspek imperatif atau normatif dan segi operatif, semua ini tidak menjamin perwujudan negara hukum jika tidak didukung oleh jiwa negara hukum dari pejabat hukum serta pemerintah dan warga negara serta rakyat. Jiwa negara itu sendiri merupakan sikap, rasa tanggung jawab, daya kekuatan dari manusia sebagai warga negara dan dalam golongan, yang memberi arah dan disiplin pemikiran serta perbuatan untuk mewujudkan negara hukum. ${ }^{21}$

Unsur-unsur negara hukum Indonesia merupakan nilai yang dipetik dari seluruh proses lahirnya negara Indonesia, dasar falsafah serta cita hukum negara Indonesia. Oleh sebab itu, kedudukan Pembukaan UUD 1945 yang juga memuat rumusan Pancasila, menjadi sumber hukum tertinggi bagi negara hukum Indonesia. Pembukaan UUD 1945 merupakan nilai abstraksi tertinggi dan nilai yang terkandung dalam pembukaan merupakan kaedah penuntun penyusunan pasal-pasal dalam UUD 1945 agar tidak menyimpang dari nilai-nilai yang menjadi dasar falsafah dan cita negara.

Pemegang kekuasaan negara dalam menjalankan kekuasaannya tentu harus berpedoman pada nilai-nilai yang menjadi dasar falsafah dan cita negara Indonesia, yang sekaligus merupakan moral ketatanegaraan. Hal ini didasarkan pada pendapat A.V. Dicey sebagaimana yang dikutip Bagir Manan, ${ }^{22}$ dikatakan bahwa ketentuan ketatanegaraan, terdiri dari 2 (dua) macam ketentuan, yaitu:

${ }^{21}$ O. Notohamidjojo, Makna Negara Hukum bagi Pembaharuan Negara dan Wibawa Hukum bagi Pembaharuan Masyarakat di Indonesia, Jakarta: Badan Penerbit Kristen, 1967, hlm. 44-45

22 Bagir Manan (2), Konvensi Ketatanegaraan, Bandung: Armico, 1987, hlm. 20. 
1. ketentuan-ketentuan (rules) yang digolongkan sebagai kaidah-kaidah hukum (law), yaitu kaidah-kaidah hukum tata negara (the law of the constitution). Termasuk kaidah-kaidah hukum tata negara adalah semua ketentuan yang penataannya dapat dipaksakan oleh (melalui) pengadilan; dan

2. ketentuan-ketentuan yang tidak termasuk sebagai kaidah hukum, yaitu konvensi ketatanegaraan atau akhlak (moral) ketatanegaraan (convention of the constitutional atau constitutional morality).

Bagir Manan lebih lanjut menjelaskan bahwa walaupun konvensi ketatanegaraan mengatur tentang cara-cara pemegang kekuasaan negara menjalankan kekuasaan, tetapi tidak tergolong sebagai kaidah hukum, karena penataan terhadap konvensi ketatanegaraan tidak dipaksakan oleh (melalui) pengadilan. Ketaatan terhadap konvensi ketatanegaraan semata-mata berdasarkan kesukarelaan atau karena dorongan etika atau akhlak. Oleh sebab itu, konvensi ketatanegaraan disebut juga etika ketatanegaraan, akhlak ketatanegaraan (constitutional ethich atau constitutional morality). ${ }^{23}$

Susunan Pancasila adalah hirarkis dan mempunyai bentuk piramidal, dan kalau dilihat dari inti isinya, maka urutan-urutan lima sila menunjukkan suatu rangkaian tingkat dalam dan luas isinya. Setiap sila yang di belakang sila lainnya merupakan pengkhususan dari sila yang di depannya, dan jika urutan masingmasing sila dianggap mempunyai maksud demikian, maka di antara lima sila ada hubungan yang mengikat satu kepada yang lain, sehingga Pancasila merupakan satu kesatuan yang bulat. Dalam susunan hirarkis dan piramidal ini, maka Ketuhanan Yang Maha Esa menjadi basis dari kemanusiaan (perikemanusian), persatuan Indonesia (kebangsaan), kerakyatan dan keadilan sosial. Sebaliknya Ketuhanan Yang Maha Esa adalah Ketuhanan Yang Maha Esa adalah yang

\footnotetext{
${ }^{23}$ Ibid.
} 
berkemanusiaan, berpersatuan (berkebangsaan), berkerakyatan dan berkeadilan sosial, demikian seterusnya ${ }^{24}$

Yudi Latif, ${ }^{25}$ mengemukakan bahwa sebagai basis moralitas dan haluan kebangsaan-kenegaraan, Pancasila memiliki landasan ontologis, epistemologis, dan aksiologis yang kuat. Setiap sila memiliki justifikasi historisitas, rasionalitas, dan aktualitasnya, yang jika dipahami, dihayati, dipercayai dan diamalkan secara konsisten dapat menopang pencapaian-pencapaian agung peradaban bangsa. Pokok-pokok moralitas dan haluan kebangsaan-kenegaraan berdasarkan alam Pancasila dapat dilukiskan sebagai berikut:

1. Nilai-nilai ketuhanan (religiositas) sebagai sumber etika dan spiritualitas (yang bersifat vertikal-transendental) dianggap penting sebagai fundamen etik kehidupan bernegara. Indonesia bukanlah negara sekuler yang ekstrem, yang memisahkan "agama" dan "negara" dan berpretensi untuk menyudutkan peran agama ke ruang privat/komunitas. Negara menurut alam Pancasila diharapkan dapat melindungi dan mengembangkan kehidupan beragama, sementara agama diharapkan dapat memainkan peran publik yang berkaitan dengan penguatan etika sosial, tetapi saat sama, Indonesia juga bukan "negara agama", yang hanya merepesentasikan salah satu (unsur) agama dan memungkinkan agama untuk mendikte negara.

2. Nilai-nilai kemanusiaan universal yang bersumber dari hukum Tuhan, hukum alam, dan sifat-sifat sosial manusia (yang bersifat horizontal) dianggap penting sebagai fundamen etika-politik kehidupan bernegara dalam pergaulan dunia. Prinsip kebangsaan yang luas yang mengarah pada persaudaraan dunia itu dikembangkan melalui jalan eksternalisasi dan internalisasi. Keluar, bangsa Indonesia menggunakan segenap daya dan khazanah yang dimilikinya untuk secara bebas-aktif "ikut melaksanakan ketertiban dunia yang berdasarkan kemerdekaan, perdamaian abadi dan keadilan sosial". Ke dalam, bangsa Indonesia dan memuliakan hak-hak dasar warga dan penduduk negeri. Landasan etik sebagai prasyarat persaudaraan universal ini adalah "adil" dan "beradab".

3. Aktualisasi nilai-nilai etis kemanusiaan itu terlebih dahulu harus mengakar kuat dalam lingkungan pergaulan kebangsaan yang lebih dekat sebelum menjangkau pergaulan dunia yang lebih jauh. Dalam internalisasi nilai-nilai persaudaraan kemanusiaan ini, Indonesia adalah negara persatuan kebangsaan yang mengatasi paham golongan dan perseorangan. Persatuan dari kebhinekaan masyarakat Indonesia dikelola berdasarkan konsepsi kebangsaan yang mengekspresikan persatuan dalam keragaman, dan

${ }^{24}$ Notonagoro (1), Pancasila Dasar Falsafah Negara, Jakarta: Rineka Cipta, Cetakan Keempat, 1988, hlm. 31.

25 Yudi Latif, Negara Paripurna: Historisitas, Rasionalitas, dan Aktualitas Pancasila, Jakarta: Gramedia Pustaka Utama, 2011, hlm. 42-46. 
keragaman dalam persatuan, yang dalam slogan negara dinyatakan dengan ungkapan "bhineka tunggal ika".

4. Nilai ketuhanan, nilai kemanusiaan, dan nilai serta cita-cita kebangsaan itu dalam aktualisasinya harus menjunjung tinggi kedaulatan rakyat dalam semangat permusyawaratan yang dipimpin oleh hikmat kebijaksanaan. Dalam visi demokrasi permusyawaratan, demokrasi memperoleh kesejatiannya dalam penguatan daulat rakyat, ketika kebebasan politik berkelindan dengan kesetaraan ekonomi, yang menghidupkan semangat persaudaraan dalam kerangka "musyawarah-mufakat". Dalam prinsip musyawarah-mufakat, keputusan tidak didikte oleh golongan mayoritas (mayorokrasi) atau kekuatan minoritas elite politik dan pengusaha (minorokrasi), melainkan dipimpin oleh hikmat/kebijaksanaan yang memuliakan daya-daya nasionalitas deliberatif dan kearifan setiap warga tanpa pandang bulu.

5. Nilai ketuhanan, nilai kemanusiaan, nilai dan cita kebangsaan, serta demokrasi permusyawaratan itu memperoleh kepenuhan artinya sejauh dapat mewujudkan keadilan sosial. Di satu sisi, perwujudan keadilan sosial harus mencerminkan imperatif etis keempat sila lainnya. Di sisi lain, otentisitas pengalaman sila-sila Pancasila bisa ditakar dari perwujudan keadilan sosial dalam perikehidupan kebangsaan. Dalam visi keadilan sosial menurut Pancasila, yang dikehendaki adalah keseimbangan antara pemenuhan kebutuhan jasmani dan rohani, keseimbangan antara peran manusia sebagai makhluk individu (yang terlembaga dalam pasar) dan peran manusia sebagai makhluk sosial (yang terlembaga dalam negara), juga keseimbangan antara pemenuhan hak sipil dan politik dengan hak ekonomi, serta sosial dan budaya.

Muhammad Tahir Azhary ${ }^{26}$ mengutip pendapat Oemar Seno Adji mengatakan bahwa: Negara Hukum Indonesia mempunyai ciri khas Indonesia, karena mempunyai pandangan hidup bernegara yaitu Pancasila. Pancasila harus diangkat sebagai dasar pokok dan sumber hukum, maka Negara Hukum Indonesia dapat pula disebut Negara Hukum Pancasila. Salah satu ciri pokok dalam Negara Hukum Pancasila adalah adanya jaminan terhadap kebebasan beragama (freedom of religion). Muhammad Tahir Azhary selanjutnya mengatakan bahwa walaupun dalam Penjelasan UUD 1945 digunakan istilah rechtstaats, tetapi yang dianut oleh Negara Indonesia bukan konsep rechtstaats dan bukan pula konsep the rule of law, melainkan konsep Negara Hukum Pancasila yang mempunyai ciri-ciri: (1) ada hubungan yang erat antara agama dan negara; (2)

${ }^{26}$ Muhammad Tahir Azhary (2), Negara Hukum: Suatu Studi tentang Prinsip-prinsipnya Dilihat dari Segi Hukum Islam, Implementasinya pada Periode Negara Madinah dan Masa Kini, Jakarta: Bulan Bintang, 1992, hlm. 69. 
bertumpu pada Ketuhanan Yang Maha Esa; (3) kebebasan beragama dalam arti

positif; (4) ateisme tidak dibenarkan dan komunisme dilarang; (5) asas kekeluargaan dan kerukunan. ${ }^{27}$ Dalam pendapat lain menurut Bernard Arief Sidharta, dikatakan bawah Negara Pancasila mempunyai ciri-ciri, yaitu:28

1. Negara Pancasila adalah negara hukum, yang di dalamnya semua penggunaan kekuasaan harus selalu ada landasan hukumnya dan dalam kerangka batas-batas yang ditetapkan oleh hukum, a fortiori untuk penggunaan kekuasaan publik. Jadi, pemerintahan yang dikehendaki adalah pemerintahan berdasarkan, dengan dan oleh hukum ("rule by law" dan "rule of law").

2. Negara Pancasila itu adalah negara demokrasi yang dalam keseluruhan kegiatan menegaranya selalu terbuka bagi partisipasi seluruh rakyat, yang di dalamnya pelaksanaan kewenangan dan penggunaan kekuasaan publik harus dipertanggungjawabkan kepada rakyat dan harus selalu terbuka bagi pengkajian rasional oleh semua pihak dalam kerangka tata nilai dan tatanan hukum yang berlaku. Selain itu, badan kehakiman menjalankan kewenangannya secara bebas, dan birokrasi pemerintahan lain tunduk pada putusan badan kehakiman, serta warga masyarakat dapat mengajukan tindakan birokrasi pemerintahan ke pengadilan. Pemerintah terbuka bagi pengkajian kritis oleh Badan Perwakilan Rakyat dan masyarakat berkenaan dengan kebijakan dan tindakan-tindakannya. ${ }^{29}$

3. Negara Pancasila adalah organisasi seluruh rakyat yang menata diri secara rasional untuk dalam kebersamaan berikhtiar, dalam kerangka dan melalui tatanan kaidah hukum yang berlaku, mewujudkan kesejahteraan lahir-batin bagi seluruh rakyat dengan selalu mengacu pada nilai-nilai martabat manusia dan Ketuhanan Yang Maha Esa. Dalam konsepsi Negara Pancasila ini, maka negara dan pemerintah lebih merupakan koordinasi berbagai pusat pengambilan keputusan rasional yang berintikan asas rasionalitas-efisiensi, asas rasionalitas-kewajaran, asas rasionalitas-berkaidah dan asas rasionalitasnilai, ketimbang organisasi kekuasaan semata-mata. ${ }^{30}$ Dengan demikian, dapat dikatakan bahwa Negara Pancasila yang dicita-citakan adalah negara hukum yang berdasarkan asas kerakyatan bertujuan untuk mewujudkan kesejahteraan berkeadilan (keadilan sosial) bagi seluruh rakyat Indonesia serta perdamaian dunia.

Padmo Wahjono, ${ }^{31}$ mengatakan ada 5 (lima) unsur formal negara hukum

Indonesia, yaitu: (1) bersumber pada Pancasila; (2) Majelis Permusyawaratan

${ }^{27}$ Idem., hlm. 71

28 Bernard Arief Sidharta (2), Refleksi tentang Struktur IImu Hukum: Sebuah Penelitian tentang Fundasi Kefilsafatan dan Sifat Keilmuan IImu Hukum sebagai Landasan Pengembangan Ilmu Hukum Nasional Indonesia, Bandung: Mandar Maju, Cetakan Ketiga, 2009, hlm. 48-49.

${ }^{29}$ Franz Magnis Suseno, Mencari Sosok Demokrasi, Jakarta: Gramedia, 1995, hlm. 58-59.

${ }^{30}$ Jurgen Habermas, Recht en Moral, Kampen: Kok Agora, 1998, hlm. 56-58.

${ }^{31}$ Padmo Wahjono (1), Op. Cit., hlm. 32. 
Rakyat merupakan lembaga tertinggi negara yang melaksanakan kedaulatan rakyat, Presiden mandataris MPR bersama-sama Dewan Perwakilan Rakyat yang merupakan bagian dari MPR merupakan lembaga pembentuk undangundang; $^{32}$ (3) Pemerintahan berdasarkan sistem konstitusi, tidak bersifat absolut; (4) segala warga negara bersamaan kedudukannya dalam hukum dan pemerintahan; dan (5) kekuasaan kehakiman yang merdeka. Pandangan lain Menurut Philipus M. Hadjon, ${ }^{33}$ dijelaskan bahwa ciri negara hukum Pancasila, yaitu: (1) keserasian hubungan antara pemerintah dan rakyat berdasarkan asas kerukunan; (2) hubungan fungsional yang proposional antara kekuasaankekuasaan negara; (3) prinsip penyelesaian sengketa secara musyawarah dan peradilan merupakan sarana terakhir; dan (4) keseimbangan antara hak dan kewajiban.

Didasarkan pada asas bahwa Pancasila merupakan sumber dari segala sumber hukum negara, maka setiap aturan hukum positif yang berlaku di Indonesia, haruslah mencerminkan nilai-nilai luhur dan murni yang terkandung dalam masing-masing Sila Pancasila dan tentunya dituntun oleh Sila Ketuhanan. Terkait dengan hal ini, menurut Darji Darmodiharjo dan Shidarta, ${ }^{34}$ dikatakan bahwa apabila filsafat hukum mengadakan penilaian terhadap hukum (apakah hukum yang ada itu sudah memenuhi rasa keadilan, kepastian hukum, dan kemanfaatan), bagi bangsa Indonesia, yang dipergunakan sebagai ukuran, alat penilai, atau batu ujiannya adalah Pancasila sebagai sumber dari segala sumber hukum, yang identik dengan pokok-pokok pikiran di Pembukaan UUD 1945.

\footnotetext{
${ }^{32}$ Sejak Amandemen dilakukan amandemen terhadap UUD 1945, kedudukan MPR tidak lagi disebut sebagai lembaga tertinggi negara.

${ }^{33}$ Philipus M. Hadjon, Perlindungan Hukum bagi Rakyat Indonesia, Surabaya: Bina IImu, 1987, hlm. 90 .

${ }^{34}$ Darji Darmodiharjo dan Shidarta, Pokok-pokok Filsafat Hukum: Apa dan Bagaimana Filsafat Hukum Indonesia, Jakarta: Gramedia Pustaka Utama,Cetakan Ketujuh, 2008, hlm. 231.
} 
Kedudukan Pancasila dalam sistem ketatanegaraan Indonesia adalah sebagai staatsfundamentalnorm. Jimly Asshiddiqie dan M. Ali Safa'at dikatakan bahwa penempatan Pancasila sebagai staatsfundamentalnorm pertama kali disampaikan Notonagoro. ${ }^{35}$ Pancasila dilihat sebagai cita hukum (rechtsidee) merupakan bintang pemandu. Posisi ini mengharuskan pembentukan hukum positif adalah untuk mencapai ide-ide dalam Pancasila, serta dapat digunakan untuk menguji hukum positif. Dengan ditetapkannya Pancasila sebagai staatsfundamentalnorm maka pembentukan hukum, penerapan dan pelaksanaannya tidak dapat dilepaskan dari nilai-nilai Pancasila. ${ }^{36}$

Ide staatsfundamentalnorm sebenarnya pernah dikembangkan oleh murid Hans Kelsen, yang bernama Hans Nawiasky, dalam karyanya yang berjudul "Allgemeine Rechtslehre als System der rechtlichen Grundbegriffe."”7 Teori yang ajarkan Nawiasky disebut dengan theorie von stufenufbau der rechtsordnung, dan susunan norma menurut teori adalah: $:^{38}$

1. Norma fundamental negara (staatsfundamentalnorm);

2. Aturan dasar negara (staatsgrundgesetz);

3. Undang-undang formal (formell gesetz); dan

4. Peraturan pelaksanaan dan peraturan otonom (verordnung en autonome satzung).

Staatsfundamentalnorm adalah norma yang merupakan dasar bagi pembentukan konstitusi atau Undang Undang Dasar (staatsverfassung) dari suatu negara. Posisi hukum dari staatsfundamentalnorm adalah sebagai syarat bagi berlakunya suatu konstitusi. Staatsfundamentalnorm ada terlebih dahulu dari

\footnotetext{
${ }^{35}$ Notonagoro (2), "Pembukaan Undang-Undang Dasar 1945 (Pokok Kaidah Fundamentil Negara Indonesia" dalam Pancasila Dasar Falsafah Negara, Jakarta: Pantjuran Tudjuh, Cetakan Keempat, t.t. Lihat Juga dalam Jimly Asshiddiqie dan M. Ali Safa'at, Teori Hans Kelsen tentang Hukum, Jakarta: Sekretariat Jenderal \& Kepaniteraan Mahkamah Konstitusi RI, Cetakan Pertama, 2006, hlm. 171.

${ }^{36}$ A. Hamid S. Attamimi, Op. Cit., hlm. 309.

37 Hans Nawiasky, Allgemeine Rechtslehre als System der rechtlichen Grundbegriffe, Einsiedeln/Zûrich/Köln: Benziger, 1948. Lihat juga dalam Jimly Asshiddiqie dan M. Ali Safa'at, Op. Cit. hlm. 170.

${ }^{38}$ A. Hamid S. Attamimi, Op. Cit. hlm. 287.
} 
konstitusi suatu negara. ${ }^{39}$ Menurut Nawiasky, norma tertinggi yang oleh Kelsen disebut sebagai norma dasar (basic norm) dalam suatu negara sebaiknya tidak disebut sebagai staatsgrundnorm melainkan staatsfundamentalnorm atau norma fundamental negara. ${ }^{40}$ Attamimi menunjukkan struktur hierarki tata hukum Indonesia dengan menggunakan teori Nawiasky, dan berdasarkan teori ini, maka struktur tata hukum Indonesia adalah: ${ }^{41}$

1. Staatsfundamentalnorm: Pancasila (Pembukaan UUD 1945).

2. Staatsgrundgesetz: Batang Tubuh UUD 1945, TAP MPR, dan Konvensi Ketatanegaraan.

3. Formell gesetz: Undang-undang.

4. Verordnung en Autonome Satzung: secara hirarkis mulai dari Peraturan Pemerintah hingga Keputusan Bupati atau Walikota.

Struktur tata hukum Indonesia sebagaimana tersebut di atas, dapat digambarkan dengan skema sebagai berikut:

\section{Struktur Tata Hukum Indonesia}

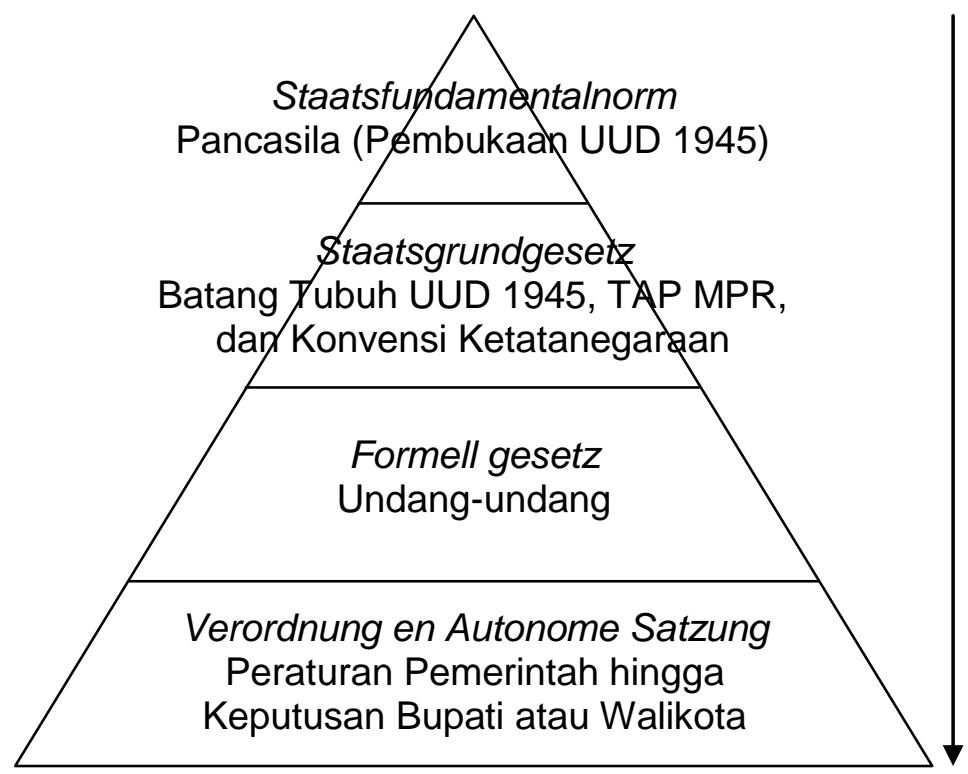

Berdasarkan gambar di atas, dapat dijelaskan bahwa kedudukan Pancasila dalam sistem ketatanegaran Indonesia yang merupakan norma

\footnotetext{
${ }^{39}$ Ibid.

${ }^{40}$ Idem., hlm. 359.

${ }^{41}$ Idem., hlm. 291.
} 
tertinggi atau disebut juga norma fundamental negara, harus dijadikan ukuran atau patokan nilai terhadap keberlakuan suatu peraturan perundang-undangan. Pencerminan nilai-nilai luhur Pancasila dalam setiap instrumen hukum yang berlaku di Indonesia inilah yang merupakan unsur pembeda antara konsep negara hukum Pancasila dengan konsep negara hukum (rechtstaats atau the rule of law) yang umumnya dikenal pada negara lain. Oleh sebab itu, hukum positif hendaknya diselaraskan dengan nilai-nilai yang terkandung dalam Sila Pancasila dan oleh sebab itu, maka setiap aturan hukum di Indonesia haruslah mencerminkan nilai-nilai luhur dan murni yang terkandung pada masing-masing Sila Pancasila.

Menurut Otje Salman ${ }^{42}$ dalam teorinya (Teori Keseimbangan Hukum) dikatakan bahwa Pancasila dapat disebut sebagai suatu sistem tentang segala hal, karena secara konseptual seluruh sila yang tertuang dalam Pancasila saling berkaitan erat dan tidak dapat dipisahkan sebagai suatu kebulatan yang utuh. Sila Pertama adalah jiwa seluruh sila yang merupakan core (inti) dari seluruh sila. Sila Pertama mencerminkan nilai-nilai spritual yang paling dalam, maka secara subtansial tidak mudah berubah.

Lebih lanjut Otje Salman ${ }^{43}$ mengatakan bahwa jika dilihat secara bulat atau holistik (satu kesatuan), yaitu dengan melihat dasar pikiran dalam Sila Pertama, Ketiga dan Kelima, maka keseimbangan (balance) merupakan substansi pokok yang terkandung di dalamnya. Keseimbangan yang dijelaskan dalam keseluruhan sila-silanya adalah keseimbangan antara kepentingan individu dengan kepentingan masyarakat serta kepentingan penguasa yang dituntun oleh Sila Ketuhanan. Berpedoman pada teori ini, maka dapat dikatakan

\footnotetext{
${ }^{42}$ R. Otje Salman S. dan Anton F. Susanto, Teori Hukum, (Mengingat, Mengumpulkan dan Membuka Kembali), Bandung: Refika Aditama, Cetakan Kedua, 2005, hlm. 159.

${ }^{43}$ Ibid.
} 
bahwa keadilan dalam perspektif Pancasila adalah keadilan yang di dalamnya ada keseimbangan kepentingan individu, kepentingan masyarakat dan negara. Oleh sebab itu, hukum nasional harus memperhatikan keadilan bagi semua pihak, yaitu keadilan yang menyeimbangkan, menyerasikan atau menyelaraskan kepentingan individu di antara kepentingan yang bersifat umum (kepentingan masyarakat dan negara).

\section{Simpulan}

Sesuai dengan makna negara hukum yang berdasarkan Pancasila, maka bangsa Indonesia memiliki sifat kebersamaan, kekeluargaan, serta sifat religius dan dalam pengertian inilah maka bangsa Indonesia pada hakikatnya dikatakan sebagai bangsa yang ber-Ketuhanan Yang Maha Esa. Rumusan Ketuhanan Yang Maha Esa sebagaimana terdapat dalam Pembukaan UUD 1945, telah memberikan sifat yang khas kepada Negara Indonesia, yaitu bukan merupakan negara sekuler yang memisahkan antara agama dengan negara dan juga bukan merupakan negara agama yaitu negara yang mendasarkan atas agama tertentu. Rumusan Ketuhanan Yang Maha Esa yang menunjukkan bahwa negara Indonesia bukan negara sekuler dan bukan pula negara agama. 


\section{DAFTAR PUSTAKA}

Buku:

Astim Riyanto, Filsafat Hukum, Bandung: Yapemdo, 2002.

Hestu Cipto Handoyo, B., Hukum Tata Negara, Kewarganegaraan \& Hak Asasi Manusia, Memahami Proses Konsolidasi Sistem Demokrasi di Indonesia, Yogyakarta: Universitas Atma Jaya, Cetakan Pertama, 2003.

Bagir Manan (ed), Kedaulatan Rakyat, Hak Asasi Manusia dan Negara Hukum, Kumpulan Essai Guna Menghormati Prof. Dr. Sri Soemantri Martosoewignyo, SH., Jakarta: Gaya Media Pratama.

, Konvensi Ketatanegaraan, Bandung: Armico, 1987.

Bernard Arief Sidharta, Refleksi tentang Struktur IImu Hukum: Sebuah Penelitian tentang Fundasi Kefilsafatan dan Sifat Keilmuan IImu Hukum sebagai Landasan Pengembangan IImu Hukum Nasional Indonesia, Bandung: Mandar Maju, Cetakan Ketiga, 2009.

Darji Darmodiharjo dan Shidarta, Pokok-pokok Filsafat Hukum: Apa dan Bagaimana Filsafat Hukum Indonesia, Jakarta: Gramedia Pustaka Utama,Cetakan Ketujuh, 2008.

Franz Magnis Suseno, Mencari Sosok Demokrasi, Jakarta: Gramedia, 1995.

Nawiasky, Hans, Allgemeine Rechtslehre als System der rechtlichen Grundbegriffe, Einsiedeln/Zûrich/Köln: Benziger, 1948.

Jimly Asshiddiqie dan M. Ali Safa'at, Teori Hans Kelsen tentang Hukum, Jakarta: Sekretariat Jenderal \& Kepaniteraan Mahkamah Konstitusi RI, Cetakan Pertama, 2006.

Habermas, Jurgen, Recht en Moral, Kampen: Kok Agora, 1998.

Krisna Harahap, HAM dan Upaya Penegakannya di Indonesia, Bandung: Grafitri Budi Utami, 2003.

Kusnardi, M. dan Harmailly Ibrahim, Pengantar Tata Hukum Negara Indonesia, Jakarta: UI-Press, 1983.

Moh. Kusnardi dan Bintan Saragih, Ilmu Negara, Jakarta: Gaya Media, Edisi Revisi, Cetakan Keempat, 2000.

Muhammad Tahir Azhary, Negara Hukum Indonesia, Jakarta: Ul-Press, 1995.

---------, Negara Hukum: Suatu Studi tentang Prinsip-prinsipnya Dilihat dari Segi Hukum Islam, Implementasinya pada Periode Negara Madinah dan Masa Kini, Jakarta: Bulan Bintang, 1992.

Notonagoro, "Pembukaan Undang-Undang Dasar 1945 (Pokok Kaidah Fundamentil Negara Indonesia" dalam Pancasila Dasar Falsafah Negara, Jakarta: Pantjuran Tudjuh, Cetakan Keempat, t.t.

, Pancasila Dasar Falsafah Negara, Jakarta: Rineka Cipta, Cetakan Keempat, 1988. 
Notohamidjojo, O., Makna Negara Hukum bagi Pembaharuan Negara dan Wibawa Hukum bagi Pembaharuan Masyarakat di Indonesia, Jakarta: Badan Penerbit Kristen, 1967.

Padmo Wahjono, Indonesia Negara Berdasarkan Atas Hukum, Jakarta: Ghalia Indonesia, Cetakan Kedua, 1986.

---------, Pembangunan Hukum di Indonesia, Jakarta: In-Hill Co., 1989.

Philipus M. Hadjon, Perlindungan Hukum bagi Rakyat Indonesia, Surabaya: Bina Ilmu, 1987.

Otje Salman S., R., dan Anton F. Susanto, Teori Hukum, (Mengingat, Mengumpulkan dan Membuka Kembali), Bandung: Refika Aditama, Cetakan Kedua, 2005.

Satjipto Rahardjo, Membedah Hukum Progresif, Jakarta: Penerbit Buku Kompas, 2006.

Sri Soemantri Martosoewignyo, R., Bunga Rampai Hukum Tata Negara Indonesia, Bandung: Alumni, 1992.

Usep Ranawijaya, Hukum Tata Negara, Dasar-dasarnya, Jakarta: Ghalia, 1983.

Yudi Latif, Negara Paripurna: Historisitas, Rasionalitas, dan Aktualitas Pancasila, Jakarta: Gramedia Pustaka Utama, 2011.

\section{Disertasi/Jurnal/Internet:}

Arif Hidayat, "Kepastian Hukum Harus Sejalan dengan Rasa Keadilan" dalam Antara News, http://www.antaranews.com, diakses tanggal 12 November 2011.

Bernard Arief Sidharta, "Kajian Kefilsafatan tentang Negara Hukum", dalam Jurnal Hukum Jentera, Jakarta: Pusat Studi Hukum dan Kebijakan (PSHK), Edisi 3-Tahun II, November 2004.

Hamdan Zoelva, "Negara Hukum dalam Perspektif Pancasila," http://www. setneg. go.id, diakses tanggal 2 November 2010.

Hamid S. Attamimi, A., "Peranan Keputusan Presiden Republik Indonesia dalam Penyelenggaraan Pemerintahan Negara: Suatu Studi Analisis Mengenai Keputusan Presiden yang Berfungsi Pengaturan dalam Kurun Waktu Pelita I-Pelita IV", Disertasi, Jakarta: Fakultas Pascasarjana Universitas Indonesia, 1990.

Rukmana Amanwinata, "Pengaturan dan Batas Implementasi Kemerdekaan Berserikat dan Berkumpul dalam Pasal 28 UUD 1945", Disertasi, Bandung: Program Pascasarjana Universitas Padjadjaran, 1996.

Tengku Erwinsyahbana, "Sistem Hukum Perkawinan pada Negara Hukum Berdasarkan Pancasila”, Jurnal Ilmu Hukum, Vol. 2 No. 2, Pekanbaru: Fakultas Hukum Universitas Riau, 2012. 